\title{
Foreword
}

This study came into being through the dedication of a single scholar, Egbertus ('Bart') van Gulik, who devoted most of his life to assembling the information it contains. It provides the most comprehensive evidence available about the books of Erasmus of Rotterdam - the books he owned and his attitude towards them, when and how he acquired them, how he housed, used, and cared for them, and how, from time to time, he disposed of them.

Part 1, originally intended by the author to be a separate monograph, tells that story. It also opens the door to a new understanding of the more intimate side of Erasmus' daily life as a scholar at home with his books, friends, publishers, and booksellers. Van Gulik's lifelong familiarity with the humanist community known to Erasmus makes of his insights a fresh and engaging introduction to the impact of Italian humanism on the more expressly Christian world of northern Europe. Part 2 is a catalogue, a carefully annotated description of all of the items contained in an inventory that was composed after Erasmus' death in July 1536. Here we find more than 400 books (some containing several works bound together) that belonged to him. They were shipped from Basel by Erasmus' executors around Christmas of that year and consigned to the Polish nobleman Jan Laski, following the terms of an agreement made with Erasmus in 1525. Laski acknowledged their receipt in early April 1537. That inventory, cryptic and highly abbreviated in form, is known as the Versandliste ('shipping invoice'). ${ }^{1}$ It is the most comprehensive list surviving of the books in Erasmus' possession at any given time, here fleshed out for the first time by van Gulik. $\mathrm{He}$ drew upon his command of bibliographical data and his extensive knowledge of Erasmus' correspondence and related records to propose as precise an identification of each of the titles as the evidence will allow. Van Gulik's annotated catalogue, along with the appendixes, which tell us what can be known of other books in Erasmus' working library and how he used them, will be of interest to students of the northern Renaissance, the history of the book, and the history of learning.

\section{Egbertus van Gulik}

Bart van Gulik was born in 1910 in the small provincial town of Hoorn on the Zuiderzee, where he also received his schooling, supplemented with private lessons in the classical languages. Following the death of his father in 1925 and of his older brother two years later, he and his mother moved to Leiden, where he entered the university in 1929. He first came into contact with the work of Erasmus while attending the lectures of Johan Huizinga, and in 1933 he took his first degree. His painstaking perfectionism prolonged his university

1 See 5 n11 below. 
studies, which concluded only in November 1941 with his doctoraal (master's) degree. At that point a proposed doctorate with a dissertation 'Jefferson's View of Europe' had to be abandoned. The German occupiers closed the university at Leiden after a student strike, provoked by a now-famous address on 26 November 1940 by the dean of the Law School, Professor Rudolph Pabus Cleveringa, protesting the dismissal of Jewish colleagues. With the assistance of his teachers van Gulik managed eventually to secure a training position in the library of the Peace Palace at The Hague, where his work on a detailed bibliography of the works of Hugo Grotius gave him his first experience of the techniques of bibliography. When, in 1950, the 700-page Bibliographie des écrits imprimés de Hugo Grotius was published, van Gulik's name appeared in the Foreword along with those of the compilers.

In 1942, on the recommendation of Huizinga, van Gulik applied for a place in the University Library at Leiden. After a year of further training there his prospects were such that in the spring of 1943 he was able to marry Tonny van Beusekom, who, like him, had been a member of the literary society Sodalicium Literis Sacrum ('a society consecrated to letters') in the university; she eventually taught Dutch at Amsterdam. By the end of the war, German police were searching everywhere for able-bodied men to supply forced labour for the Third Reich, and near-starvation conditions prevailed throughout the country. Nevertheless Bart and Tonny van Gulik survived, and in 1946, four years after joining the library, he was made Keeper of Printed Books. In October 1960 Leiden University appointed him scholarly officer responsible for bibliographical documentation in the field of general history.

In 1961 van Gulik was placed in charge of the City Library of Rotterdam, a central library with ten branches and children's libraries, and four lending departments. Within its holdings of some half-million books was the largest assemblage of Erasmiana in the world. His predecessor in the post was Cornelis Reedijk, a classical scholar and one of the original promoters of a new, critical edition of the works of Erasmus. ${ }^{2}$ The edition was launched by the Royal Dutch Academy (Royal Netherlands Academy of Arts and Sciences) in 1963. Van Gulik, by now an expert bibliographer, started to assemble a bibliography of printed editions of Erasmus in support of the project in the following year. It grew in time to cover the holdings of nearly 600 libraries. In 1969, to mark the publication of the first volume of the critical edition, a three-day international congress was held in Rotterdam, which included a great exhibition in the Boymans-van Beuningen Museum. Van Gulik was largely instrumental in the creation of this exhibition and its invaluable two-volume catalogue, Erasmus en zijn tijd. Among the documents shown there (no 543 in the catalogue) was the Versandliste from the archives of the University Library in Basel. As has been mentioned, this inventory supplied the titles of some 400 books in very abbreviated form. What was it, exactly? And what books did Erasmus actually have in his personal collection? These questions were to occupy van Gulik for the rest of his life. In 1973 he took early retirement to have more time for scholarly work, chiefly the virtual reassembling of Erasmus' library, and he moved from Rotterdam to live again near Leiden, at Oegstgeest.

On learning of van Gulik's enterprise from Sir Roger Mynors, a scholarly sponsor of the new critical edition of Erasmus' Opera omnia and also a founding editor and translator of the Collected Works of Erasmus, this writer paid the first of what was to be a series of

2 Earlier editions of the Opera omnia Desiderii Erasmi Roterodami had appeared at Basel (1538-40) and Leiden (1703-6). The Leiden edition is commonly cited as LB. For background to the new edition in question, see James McConica 'Erasmus in Amsterdam and Toronto.' 
visits to van Gulik's apartment at Oegstgeest in October of 1978, bearing the news that the University of Toronto Press would be distinctly interested in publishing his work, by this time already quite far advanced. This encouraging prospect proved insufficient, however, to overcome van Gulik's deeply ingrained caution and perfectionism; there was always something to add. Some time later he broke his hip and had to undergo a succession of four surgeries; the invaluable support of his wife, Tonny, faded as her own health declined, and she succumbed eventually in 1995. It was only with his death in 1998 that the much-revised yet still incomplete version of his edition of the Versandliste became available. It runs to more than 1,100 manuscript pages. Other important supporting materials among his extensive papers were subsequently put in order by Johannes Trapman, Secretary of the Council in charge of the critical edition of Erasmus' Opera omnia, and yet others were identified by his daughter, Mme Schram-van Gulik, whose patient examination of her father's papers rescued even items of which we had despaired.

\section{The Story of Erasmus and His Books}

In the following pages the reader will find the remarkable harvest of Bart van Gulik's perseverance and erudite investigation. In the Introduction he summarizes the background to his work on the Versandliste and gives a brief history of the slow dispersal of the books sent to Laski in the lifetime of their new owner, as Laski joined the Reform and wandered through Europe. After adding an account of the modern search for books that are identified as formerly in Erasmus' possession - usually through the unmistakable ex libris Sum Erasmi (roughly, 'I belong to Erasmus') penned on an endpaper - he outlines his intentions in what follows.

The scope of van Gulik's study is fairly indicated by the successive chapter headings in Part 1, 'The History and Nature of Erasmus' Working Library.' Here the reader will find assembled van Gulik's conclusions, drawn from his years of work on the Versandliste and amplified by his extensive experience of Renaissance bibliography and his familiarity with Erasmus' life. He comments upon the focus and range of Erasmus' interest in books, his utilitarian attitude to them (he was no bibliophile), how he and other humanists acquired and exchanged them, how he regarded manuscripts, how he undertook binding and maintenance, how he stored, arranged, and cared for his books, and how he moved them about. The first five chapters give us the evidence to reconstruct Erasmus' library. They are followed at chapter 6, 'Erasmus and the Book: The Humanist at Work,' by a surprisingly intimate portrait of Erasmus among his books and of his working habits and discipline: being read to by his scholar-pupils, keeping up with new publications, dealing with his own publisher, taking his favourite authors - his familiar 'travelling companions' - with him when, as so often, he was on the road. Part 1 concludes with an assessment of Erasmus' collection as representative both of his personal circumstances and of the age in which he lived: it was the working reference library of a Christian humanist in the new age of printing.

The core of van Gulik's research, and of this volume, is contained in Part 2, the annotated catalogue, in which the Versandliste, a record of the books in Erasmus' possession at the time of his death, is for the first time amplified with all of the evidence that could be brought to bear upon it. In his Introduction to the annotated catalogue van Gulik describes the procedures he used in approaching the individual works there listed in order to supply as precise an identification of each entry as possible. In the course of doing this, he provides the reader with a wealth of information about the history of the book and the book trade, 
about Erasmus' attitudes and procedures as a humanist, and about the limits to our knowledge of both.

Supplementing the Versandliste/Catalogue are two appendixes. The first, the Catalogus librorum Erasmi, is a list compiled after Erasmus' death of 112 mostly unbound works written or edited by Erasmus and probably found by his executors in his final residence in Basel, where they were kept in a chest. The second appendix is a further list, assembled by van Gulik, of 153 works that, judging from his correspondence, were in Erasmus' possession but are not found either in the Versandliste or in the Catalogus librorum.

JAMES K. MC CONICA

\section{Acknowledgments}

In composing this memoir of Drs van Gulik I must acknowledge the invaluable assistance of his daughter, the late Mme M.E. Schram-van Gulik of Wijdenes, the Netherlands. I am also indebted to the Levensbericht 'Egbertus van Gulik' by Drs E. Meeldijk in Jaarboek van de Maatschappij der Nederlandse Letterkunde te Leiden 2000-2001, and to Dr J.C. Grayson, who translated it; to J.J.M. van de Roer-Meyers, formerly of the Rotterdam City Library; and to Prof Dr H.J. de Jonge, formerly of Leiden University. In the matter of publication, the Conseil international pour l'édition des oeuvres complètes d'Erasme has assisted with a timely and generous subvention. Several colleagues provided generous assistance, especially Prof John N. Grant of the University of Toronto. Finally, this volume's appearance is of itself a tribute to the dedication and meticulous editorial skills of Mary Baldwin of University of Toronto Press. 